\title{
PODA NA LIMA SEBAGAI KONSEP LITERASI MEDIA DALAM MEMFILTERISASI BERITA HOAX
}

(Studi Pada Dosen dan Mahasiswa Fakultas Dakwah dan Ilmu Komunikasi IAIN Padangsidimpuan)

\section{Barkah Hadamean Harahap}

Dosen Fakultas Dakwah dan Ilmu Komunikasi IAIN Padangsidimpuan e-mail: berkah.kedamaian@gmail.com

\begin{abstract}
The focus of this research is the understanding of lecturers and students about poda na lima of keep your soul clean and media literacy in filtering the news circulating in online media with the concept of poda na lima it is focused on the concept of local wisdom with regional philosophical principles, namely paias rohamu (cleansing your soul) in students and lecturers of the Da'wah and Communication Faculty of IAIN Padangsidimpuan. The purpose of this study was to find out about the understanding and efforts of lecturers and students about the poda na lima of keep your soul clean as a form of the concept of media literacy in filtering hoax news. The type of research is qualitative with the subject of this research carried out by random sampling. The instruments used interviews as the main technique of the research, then strengthened by and documentation and observation. The results of the study show that the understanding of lecturers and students about the poda na lima of keep your soul clean as a form of media literacy concept is not materially raised but rather the content value of the five pillars of your spirit. To instill the five pillars of keep your soul clean as a form of media literacy filtering hoax news, the lecturer strives to provide an understanding of self-concept according to the subject area of the student through classroom learning. Producing messages as part of message creativity is the ability of someone to arrange messages or ideas with words, sounds, or images effectively in accordance with the principles of communication science.
\end{abstract}

Keywords: Clean your body, literation, and Hoax

\section{Abstrak}

Fokus penelitian ini adalah pemahaman dosen dan mahasiswa tentang poda na lima paias rohamu dan literasi media dalam memfilter berita-berita yang beredar pada media online dengan konsep poda na lima yang difokuskan pada konsep kearifan lokal dengan prinsip filosofis kedaerahan yaitu paias rohamu (bersihkan jiwamu) di kalangan mahasiswa dan dosen Fakultas Dakwah dan Ilmu Komunikasi IAIN 
Padangsidimpuan. Tujuan penelitian ini adalah dalam rangka mencari tahu tentang pemahaman dan upaya dosen dan mahasiswa tentang poda na lima paias rohamu (bersihkan jiwamu) sebagai bentuk konsep literasi media dalam memfilter berita hoax. Jenis penelitian yang digunakan peneliti adalah kualitatif dengan subjek penelitian ini dilaksanakan dengan cara random sampling dengan instrumen yang digunakan dalam pengumpulan data, secara keseluruhan data dikumpulkan melalui wawancara sebagai teknik utama dari penelitian, kemudian dikuatkan dengan dan dokumentasi dan observasi. Hasil penelitian menunjukkan bahwa pemahaman dosen dan mahasiswa tentang poda na lima paias rohamu (bersihkan jiwamu) sebagai bentuk konsep literasi media tidak diangkat secara material tetapi lebih pada nilai kandungan dari poda na lima paias rohamu. Upaya dosen dan mahasiswa dalam menanamkan poda na lima paias rohamu (bersihkan jiwamu) sebagai bentuk literasi media memfilter berita hoax adalah dimana dosen lebih berupaya memberikan pemahaman tentang konsep diri sesuai bidang mata kuliahnya pada mahasiswa melalui pembelajaran di dalam kelas. Memproduksi pesan sebagai bagian dari kreativitas pesan adalah kemampuan seseorang menyusun pesan atau ide dengan kata-kata, suara, atau imej secara efektif sesuai dengan kaidah-kaidah ilmu komunikasi.

Kata Kunci: Paias Rohamu, Literasi, Hoax

\section{PENDAHULUAN}

Media tidak hanya sekedar memberikan informasi dan hiburan semata, tetapi juga mengajak khalayak untuk melakukan perubahan sikap dan prilaku. Salah satu komponen yang paling penting dalam memahami media adalah konsep literasi media. Perspektif seseorang dalam memahami pesan media dilihat dalam menyikapi setiap pesan yang datang kepadanya dan bagaimana dia bersikap. Sering kali di media ditayangkan iklan kosmetik dengan komitmen yang ditawarkan akan menjadi menarik, terlihat putih cantik, disukai banyak orang. Namun ternyata realitas yang ditampilkan iklan tidak seindah dengan kenyataan yang terjadi pada diri seseorang. Demikian pula ketika membaca berita online terutama dari aplikasi smartphone menyajikan informasi tentang isu perkembangan politik banyak berita yang dibesar-besarkan hingga membentuk citra dari tokoh tertentu baik di mata publik atau sebaliknya.

Pada kondisi ini sering kali persepsi khalayak dibentuk oleh pesan media massa dan online, gambaran realita yang ditampilkan berita, iklan dan film kemudian membentuk persepsi terhadap sebagian orang tentang cara dia memandang dunia nyata. Kebanyakan apa yang terjadi di otak kita tidak pernah 
kita sadari. Walaupun aktivitas ini sering kali mempengaruhi pikiran sadar kita, hal tersebut tidak secara langsung mempengaruhi proses kognitif lainnya. Kesadaran kita bertindak sebagai pengawas tertinggi dari aktivitas kognitif ini, tetapi hanya mampu mengontrol secara tebatas dan tidak langsung. ${ }^{1}$

Peranan pendidikan literasi media hadir guna memberikan wawasan, pengetahuan sekaligus keterampilan kepada pengguna media untuk mampu memilah dan menilai isi media massa yang dapat dipakai sekaligus juga berpikir secara kritis.Lerasi media memang belum begitu berkembang di Indonesia dibanding negara lain seperti Amerika, Australia dan Demnark. Khalayak masih menjadikan media berfungsi tunggal yakni sebagai media tontonan saja belum bergeser kepada objek kajian dan penelitian yang diharapkan ada hasil evaluasi keilmuan untuk disosialisasin kepada masyarakat.

Apriadi Tamburaka (1995) membagi kendala yang menyebabkan pelambatan literasi media menjadi tiga yakni tekanan dan eforia kebebasan pers, konsumersime media dan literasi belum menjadi kurikulum resmi. Inggris tercatat mengembangkan literasi media sekitar tahun 1930-an. Sedangkan Australia memberikan studi media pada level pendidikan sekolah usia 11-12 tahun. Lain halnya di Amerika, pendidikan literasi media menjadi minat tersendiri sejak tahun 1920-an ketika para guru sekolah menengah memulai dengan film untuk mengembangkan pemikiran dan keahlian berkomunikasi siswa yang kritis. Pada tahun 1950-1960 kosa kata film merupakan pendekatan kepada pendidikan melek media yang berkembang di dalam Amerika Serikat. ${ }^{2}$

Kehadiran ragam media yang mulai memadati segala bidang kehidupan manusia ditanggapi positif oleh sebagian besar mahasiswa di IAIN Padangsidimpuan terutama dosen dan mahasiswa. Walaupun begitu, hanya sebagian kecil sadar bahwa kehadiran media juga tidak terlepas dari dampak negatifnya. Sebagian dari dosen dan mahasiswa dari juga beranggapan, media memiliki peran strategis dalam proses komunikasi khususnya komunikasi massa dan media online. Hampir seluruh dosen dan mahasiswa menyatakan bahwa informasi yang terkandung dalam media massa dan online dapat membantu terjadinya komunikasi diantara mahasiswa, masyarakat dan sesama pengawai di kalangan civitas akademik Fakultas Dakwah dan Ilmu Komunikasi IAIN

\footnotetext{
${ }^{1}$ Stanley J. Baran, Pengantar Komunikasi Massa: Literasi Media dan Budaya, Edisi Kelima Buku Satu, (Jakarta: Salemba Humanika, 2011), hlm. 311.

${ }^{2}$ Ibid, hlm. 23.
} 
366 | TAZKIR: Jurnal Penelitian Ilmu-ilmu Sosial dan Keislaman

Vol. 04 No. 2 Desember 2018

Padangsidimpuan dan media juga dapat membentuk suatu opini tertentu ditengah-tengah civitas akademik IAIN Padangsidimpuan tentang berbagai hal yang terjadi.

Kemampuan literasi media, khususnya media online, wajib dimiliki para mahasiswa jika tidak ingin tertinggal dan menjadi asing di antara lingkungan yang sudah diterpa arus informasi digital. Diharapkan, literasi media para mahasiswa akan penggunaan media Internet dapat mengurangi efek buruk dari penggunaan media tersebut dan juga informasi yang tidak dapat dipungkiri merembet pada hal negatif seperti: konsumerisme, budaya kekerasan, budaya ngintippribadi orang, bahkan kematangan seksual lebih cepat terjadi pada usia anak-anak. ${ }^{3}$

Realitasnya, dosen dan mahasiswa yang memiliki keterampilan literasi media tidak akan langsung mempercayai sebuah berita sebelum mengkrosceknya dengan sumber lain. Jika berita tersebut adalah tidak benar adanya maka disebut berita hoax atau berita palsu.Kebiasaan yang dilakukan oleh sebagian dosen dan mahasiswa di Fakultas Dakwah dan Ilmu Komunikasi IAIN Padangsidimpuan biasa dilakukan adalah memilih media yang diakui kredibilitasnya, mengkroscek keakuratan berita dengan sumber lain, dan akan selalu mencari kelengkapan suatu berita yang didengarnya dari orang lain di dalam suatu media massa. Bila dibandingkan dengan ketiga hal tersebut, artinya tidak semua dosen dan mahasiswa memahami literasi media dengan baik.

Dengan demikian peneliti berharap melalui penelitian ini literasi media berbasis kearifan lokal dengan konsep poda na lima menjadi kerangka acuan dalam berbagai tatanan komunikasi yang efektif. Terutama dalam merumuskan sistem perkuliahan, tradisi keilmuan, pengetahuan dan penerapan dalam mata kuliah dan peningkatan mutu pendidikan di Fakultas Dakwah dan Ilmu Komunikasi di IAIN Padangsidimpuan.

Adapun fokus penelitian ini adalah pengetahuan dan pemahaman para mahasiswa dan dosen tenaga pengajar tentang literasi media dalam memfilter berita-berita yang beredar pada media online dengan konsep poda na lima yang difokuskan pada konsep kearifan lokal dengan prinsip filosofis kedaerahan yaitu paias rohamu (bersihkan jiwamu) di kalangan mahasiswa dan dosen Fakultas

${ }^{3}$ A. Rahmi. Pengenalan Literasi Media Pada Anak Usia Sekolah Dasar. Jurnal SAWWA, 2013. No. 8 Vol 2, hlm. 261-275. Diakses dari http://journal.walisongo.ac. id/index.php/sww/ article/view/116 
Dakwah dan Ilmu Komunikasi IAIN Padangsidimpuan. Selanjutnya upaya yang dilaksanakan dosen dan mahasiswa dalam menerapkan prinsip kearifan lokal konsep paias rohamu (bersihkan jiwamu) sebagai filter diri dari berita-berita hoax yang beredar di media online.

Adapun tujuan penelitian ini adalah untuk mengetahui 1) pemahaman dosen dan mahasiswa tentang poda na lima paias rohamu (bersihkan jiwamu) sebagai bentuk konsep literasi media dalam memfilter berita hoax dan 2) upaya dosen dan mahasiswa dalam menanamkan poda na lima paias rohamu (bersihkan jiwamu) sebagai bentuk literasi media memfilter berita hoax?

Terkait dengan tujuan penelitian tersebut, maka penelitian ini diharapkan memberi manfaat secara teoritis maupun secara praktis. Secara praktis bahwa penelitian ini berguna untuk meningkatkan dan menambah khazanah ilmu pengetahuan tentang kearifan lokal filosofis dalam tatanan bermasyarakat Angkola Mandailing dalam melawan berita-berita hoax. Secara praktisnya, penelitian ini diharapkan bemanfaat bagi beberapa pihak yaitu:

1. Bagi para mahasiswa penelitian ini nantinya akan bermanfaat sebagai bahan bacaan dan referensi dalam menambah pengetahuan terutama di bidang literasi media dalam mempelejari dan melawan hoax.

2. Bagi para dosen tenaga pengajar diharapkan menjadi bahan dan referensi dalam meningkatkan pemahaman tentang pengetahuan kearifan lokal dan literasi media dalam melawan hoax.

3. Bagi peneliti lain yang ingin meneliti tentang kearifan lokal Angkola Mandailing sehingga penelitian ini menjadi lebih sumber rujukan awal.

4. Bagi masyarakat sebagai bentuk pengetahuan tentang literasi media dalam menolak berita-berita hoax.

\section{KAJIAN TEORI}

\section{Konsep Poda Na Lima}

Poda ialah ajaran dan didikan yang baik yang menjadi pedoman hidup. ${ }^{4}$ Dengan demikian poda na lima adalah dasar ajaran, didikan, nasehat, tuntunan, peringatan, tatanan, norma, etika, moral, hukum dan tausiah yang merupakan pedoman hidup (way of life), dalam hubungan komunikasi antara manusia dalam pergaulan hidup, yang selalu saling membutuhkan dan isi mengisi berbagai

${ }^{4}$ Sutan Tinggi Barani Perkasa Alam, Pembaharuan dan Modernisasi Adat Budaya Tapanuli Selatan Adat Hombar Dohot Ibadat dalam Pelaksanaan, (Padangsidimpuan, TP, 2005), hlm.8. 
kepentingan hidup. ${ }^{5}$ Sejak kecil para orangtua dulu memberikan pendidikan pekerti kepada anak-anaknya melalui poda na lima ini. dan ini dianggap manjur sebagai upaya menjadikan geerasi yang berbudi pekerti luhur.

Falsafah poda na lima (lima nasehat) terdiri dari: paias rohamu, Paias pamatangmu, paias parabitonmu, paias bagasmu, paias pakaranganmu. ${ }^{6}$ Adapun poda na limayang menjadi fokus bahasan ialah paias rohamu (bersihkan hatimu atau jiwamu). Hati merupakan pusat pemerintahan diri seseorang, hati memiliki kendali yang sangat signifikan yang dapat menentukan seseorang dalam berbuat benar dan salah.

Dalam konsep ajaran Islam, Nabi Muhammad Saw menyebut bilamana hati seseorang itu baik maka baiklah seluruh tubuhnya, begitu juga bila mana hatinya buruk maka buruklah semua anggota badannya. Diriwayatkan dari anNu'man bin Basyir, dia berkata, “Rasulullah bersabda Ketahuilah sesungguhnya di dalam jasad itu ada segumpal darah. Apabila dia baik, maka menjadi baik pula semua anggota tubuhnya. Dan apabila rusak, maka menjadi rusak pula semua anggota tubuhnya. Ketahuilah dia itu adalah hati. ${ }^{7}$

Berkaitan dengan konsep paias rohamu yang merupakan bagian pertama dari 5 petuah orangtua di tanah Angkola-Mandailing, sangat penting ditekankan bahwa kebersihan jiwa adalah hal mendasar dalam konsep agama Islam. Sebagaimana disebutkan di atas. Setiap perbuatan yang dilakukan oleh manusia selalu dilandaskan oleh hati. Terkadang atau bahkan sering memahami baikburuknya perbuatan yang kita lakukan tentunya berdampak baik bagi diri sendiri maupun orang lain. Karena setiap manusia memiliki kesadaran, dari hati melalui kinerja otak dan tindakan manusia.

Penerapan konsep poda na lima paias rohamu telah dirumuskan dalam ajaran agama Islam yakni obat hati yang paling mujarab, yaitu membaca AlQur'an. Apabila mendapat musibah dengan beristighfar, bukan malah menyerapahi keadaaan atau orang-orang sekitar. Hal ini bertujuan agar hati terjaga dari sifat sombong sehingga apabila dihadapkan suatu masalah, dapat diselesaikan dengan lapang dada. Sifat dendam yang bersarang di hati yang

${ }^{5}$ Zainal Efendi Hasibuan dan Sutan Tinggi Barani Perkasa Alam, Studi Komprehensif Adat Budaya Batak Angkola Menelusuri Jejak Nilai- Nilai Luhur Adat Budaya dan Agama Ditanah Batak Angkola dalam Membentuk Generasi Muda yang Berkarakter dan Beradab, (Padangsidimpun, TP, 2013), hlm.9.

${ }^{6}$ Sutan Tinggi Barani Perkasa Alam dan Zainal Efendi Hasibuan, Adat Budaya Batak Angkola Menelusuri Perjalanan Masa, (Medan: Parmata Mitra Sari, 2015), hlm.15.

7 Imam An-Nawawi. Matan Hadits Arba'in An-Nawawi. (Solo: Insan Kamil, 2013), hlm. 5. 
tentunya dapat mengotori hati. Manusia sesama harus saling menjaga temanteman dari keburukan karena sebagaimana dikemukakan sebelumnya, baiknya hati ditopang oleh ajaran agama yang sesuai dengan filosofis budaya.

\section{Konsep Literasi Media}

Konsep tentang literasi media dalam bahasan ini menjadi teori yang dipakai. Penjabaran tentang literasi media hanya difokuskan pada konsep dasar, meliputi pengertian, tujuan dan ruang lingkup serta adanya penerapan literasi media di lingkungan perguruan tinggi.

Literasi media seringkali diterjemahkan secara sederhana dengan 'melek media'. Pandangan semacam ini dianggap menyederhanakan persoalan pengembangan kapasitas literasi media, karena apabila dianalogikan dengan melek huruf maka literasi media dapat diartikan hanya sebagai 'sekedar' tidak buta media. Literasi media diartikan sebagai suatu kemampuan untuk mengakses, menganalisis, dan menciptakan. ${ }^{8}$ Pemahaman literasi media mencakup kemampuan untuk membaca teks film, televisi, dan media visual karena studi tentang pendidikan media dimulai dengan mengikuti pengembangan area media.

Silverblatt memberikan mengemukakan suatu upaya sistematis untuk menjadikan melek media atau literasi media sebagai bagian dari orientasi terhadap budaya khalayak. Silverblatt mengidentifikasi 5 elemen literasi media/melek media yaitu:

1) Kesadaran akan dampak media pada individu dan masyarakat

2) Pemahaman atas proses komunikasi massa

3) Pengembangan strategi untuk menganalisis dan mendistkusikan pesan media.

4) Kesadaran atas konten media sebagai sebuah teks yang memberikan pemahaman kepada budaya kita dan diri kita sendiri

5) Pemahaman kesenangan, pemahaman dan apresiasi yang ditingkatkan terhadap konten media. ${ }^{9}$

Jelas bahwa literasi media atau melek media bukanlah pengetahuan atau pendidikan tentang media semata, tetapi bergerak lebih jauh lagi yaitu melihat pengaruh buruk yang dapat ditimbulkan dari pesan-pesan media dan belajar

${ }^{8}$ Silverblatt Art. Media Literacy: Key To Interprenting Media Massages. (USA: Publisher Preager, 1995), hlm. 13.

9Silverblatt Art. Media Literacy: Key To Interprenting Media Massages. (USA: Publisher: Preager, 1995), hlm. 2-3. 
370 | TAZKIR: Jurnal Penelitian Ilmu-ilmu Sosial dan Keislaman

Vol. 04 No. 2 Desember 2018

mengantisipasinya. Terdapat tujuh kecakapan atau kemampuan yang diupayakan muncul dari kegiatan literasi media yaitu:

1) Menganalisa pesan media

Kompetensi berikutnya adalah kemampuan menganalisa struktur pesan, yang dikemas dalam media, mendayagunakan konsep-konsep dasar ilmu pengetahuan untuk memahami konteks dalam pesan pada media tertentu.

2) Menilai pesan media

Setelah mampu menganalisa, maka kompetensi berikutnya yang diperlukan adalah membuat penilaian (evaluasi).

3) Pengelompokan pesan media

Pengelompokan ini dilakukan dengan menentukan setiap unsur yang sama dalam beberapa cara: menentukan setiap unsur yang berbeda dalam beberapa cara.

4) Analisis Induksi dan Deduksi

Analisis induksi dapat digunakan dalam mengambil dan menyimpulkan suatu pola di set kecil elemen dalam pesan media. Pola generalisasi untuk semua elemen dalam himpunan pesan-pesan yang akan diliterasi tersebut akan terlihat dengan jelas maksud dan makna dari pesan tersebut.

5) Sintesis kesimpulan

Setelah mempelajari berbagai pesan-pesan media yang muncul kemudian dapat dirakit ke dalam unsur-unsur makna penting sehingga membentuk struktur baru.

6) Membuat abstrak

Menciptakan uraian singkat, jelas, dan gambaran tepat menangkap esensi dari pesan dalam sejumlah kecil kata-kata dari pada pesan itu sendiri. ${ }^{10}$

\section{Mengenal Berita Hoax}

Hoax berasal dari bahasa Inggris yang artinya tipuan, menipu, berita bohong, berita palsu dan kabar burung. Dalam Kamus Bahasa Indonesia hoax

${ }^{10}$ W. James Potter, Theory of Media Literacy: A Cognitive Approach (London:Sage, 2004), hlm. 124. 
diterjemahkan menjadi hoaks yang diartikan dengan "berita bohong". ${ }^{11}$ Menurut Wikipedia, hoax merupakan sebuah pemberitaan palsu yakni sebuah usaha untuk menipu atau mengakali pembaca dan pendengarnya agar mempercayai sesuatu. ${ }^{12}$ Biasanya seorang yang menyebarkan berita hoax secara sadar melakukan suatu kebohongan dan menyebarkan informasi yang tidak benar. Hal ini bertujuan menggiring opini dan kemudian membentuk persepsi terhadap suatu informasi. ${ }^{13}$

Menurut Dewan Pers Indonesia, ciri-ciri berita hoax adalah sebagai berikut:

1) Mengakibatkan kecemasan, kebencian, dan permusuhan.

2) Sumber berita tidak jelas. Hoax di media sosial biasanya pemberitaan media yang tidak terverifikasi, tidak berimbang, dan cenderung menyudutkan pihak tertentu.

3) Bermuatan fanatisme atas nama ideologi, judul, dan pengantarnya provokatif, memberikan penghukuman serta menyembunyikan fakta dan data. ${ }^{14}$

Dalam melawan hoax dan mencegah meluasnya dampak negatif hoax, pemerintah pada dasarnya telah memiliki payung hukum yang memadai. Pasal 28 ayat 1 dan 2 UU No. 11 tahun 2008 tentang ITE, Pasal 14 dan 15 UU No. 1 tahun 1946, Pasal 311 dan 378 KUHP, serta UU No. 40 tahun 2008 tentang Penghapusan Diskiriminasi Ras dan Etnis merupakan beberapa produk hukum yang dapat digunakan untuk memerangi penyebaran hoax.

\section{Metodologi Penelitian}

Penelitian ini dilaksanakan di Fakultas Dakwah dan Ilmu Komunikasi Institut Agama Islam Negeri Padangsidimpuan. Adapun waktu penelitian ini selama satu tahun yaitu mulai awal bulan Januari 2018 hingga Desember 2018 dengan dibiayai oleh pemerintah melalui program penelitian dosen BOPTN.

\footnotetext{
${ }^{11}$ Tim Penyusun, Kamus Bahasa Indonesia, (Jakarta: Departemen Pendidikan dan Kebudayaan, 2008), hlm. 345.

${ }^{12}$ Wikipedia, Pemberitaan Palsu, Diakses pada laman: https://id.wikipedia.org/wiki/ Pemberitaan_palsu, Diakses 21 Juni 2017.

13Jan H. Brunvand, Encyclopedia of Urban Legends. (W. W. Norton \& Company, 2001), hlm. 194.

${ }^{14}$ Yosep Adi Prasetyo Ketua Dewan Pers Indonesia, Ini Ciri-ciri Hoax Menurut Ketua Dewan Pers, Diakses dan dimuat pada Laman: https://www.bnpt.go.id/ini-ciri-ciri-hoax-menurut-ketuadewan-pers.html
} 
Jenis penelitian yang digunakan peneliti adalah kualitatif, yang dimaksudkan untuk menyelidiki keadaan, kondisi atau hal lain-lain tanpa mengubah, menambah atau mengadakan manipulasi terhadap objek yang diteliti. ${ }^{15}$ Tujuan dari penelitian deskriptif ini adalah untuk membuat deskipsi, gambaran atau lukisan secara sistematis, factual dan akurat mengenai fakta-fakta, sifat-sifat serta hubungan antar fenomena yang diselidiki. ${ }^{16}$ Subjek penelitian ini dilaksanakan dengan cara random sampling yakni peneliti memilih mahasiswa dan dosen secara acak dari seluruh di Fakultas Dakwah dan Ilmu Komunikasi yang mampu menjawab berbagai kebutuhan data penelitian ini. Sumber data disebut responden, yaitu orang yang merespon atau menjawab pertanyaan peneliti, baik pertanyaan tertulis maupun lisan. Data dalam penelitian ini berupa berupa hasil dari wawancara dan catatan peneliti (log book). Adapun sumber data penelitian ini adalah mahasiswa dan dosen di Fakultas Dakwah dan Ilmu Komunikasi IAIN Padangsidimpuan.

Adapun instrumen yang digunakan dalam pengumpulan data, secara keseluruhan data dikumpulkan melalui wawancara sebagai teknik utama dari penelitian, kemudian dikuatkan dengan dan dokumentasi dan observasi. Datadata yang telah dihimpun dengan cara wawancara dan dokumentasi kemudian ditabulasi, dikategorisasi dan kemudian dianalisis secara kualitatif dengan pendekatan deskriftif. Analisa data dalam penelitian ini dilakukan dengan dua tahapan. Yakni tahap pertama pada saat berlangsungnya proses pengumpulan data, sedangkan tahap kedua setelah semua data terkumpul dilakukan analisis data. Proses analisa data di lapangan dilakukan adalah untuk memeriksa, menyeleksi dan mengkategorikan data data yang sudah dihimpun baik data yang berasal dari hasil wawancara, observasi maupun studi dokumen. Hal ini dilakukan untuk menghindari kekeliruan dalam pengamatan dan pencatatan data, sehingga dapat memperkecil tingkat kesalahan dalam proses interpretasi data tersebut. Setelah seluruh data yang diperlukan terkumpul maka analisa data ini diawali dengan mengelompokkan seluruh data dan informasi yang diperolah, Selanjutnya dilakukan proses interpretasi untuk memberikan makna terhadap seluruh data yang ada kaitannya dengan permasalahan yang diteliti yakni penerapan literasi media dengan konsep kearfian lokal poda nalima paias rohamu

\footnotetext{
${ }^{15}$ Sugiyono, Memahamai Penelitian Kualitatif, (Bandung: Penerbit Alfabeta, 2005) hlm. 147 ${ }^{16}$ Suharsimi Arikunto, Metode Penelitian Teori dan Praktek, (Jakarta: Rajawali, 2010), hlm. 86.
} 
pada mahasiswa dan dosen di Fakultas Dakwah dan Ilmu Komunikasi IAIN

Padangsidimpuan.

\section{HASIL PENELITIAN DAN PEMBAHASAN}

\section{Pemahaman Dosen dan Mahasiswa tentang Poda na Lima Paias} Rohamu sebagai Bentuk Konsep Literasi Media dalam Memfilter Berita Hoax

Berdasarkan hasil penelitian melalui instrument pengumpulan data di lapangan penelitian. Pembahasan dalam menjawab rumusan masalah pertaman dalam penelitian dimulai dari deskripsi tentang pemahaman dosen tentang konsep poda na lima paias rohamu sebagai bentuk literasi media untuk memfilter berita hoax.

a. Pemahaman Dosen Fakultas Dakwah dan Ilmu Komunikasi tentang Konsep Poda Na Lima Paias Rohamu

Beberapa poin penting dalam menjelaskan konsep poda na lima pada poin pertama paias rohamu dapat dijabarkan sebagai berikut:

1) Makna Istilah Poda Na Lima

Falsafah dari tanah Angkola Mandailing, telah disebutkan di sana adanya Poda Na Lima (kebaikan lima hal) adapun disebutkan yang erat kaitannya dengan kecintaan diri dengan lingkungan. Orang-orang tua di tanah Angkola Mandailing masih hapal dengan kaidah-kaidah tersebut. Dulu merupakan petuah turun temurun di kalangan orang Angkola Mandailing hingga kini ironisnya kaidah-kaidah tersebut semakin dilupakan. ${ }^{17}$ Dengan poda na lima ini sudah menunjukkan jati diri akan semua yang dibutuhkan setiap individu dalam melaksanakan misinya di tengah-tengah masyarakat, dan sudah dapat dipastikan semua unsur yang mengotori jiwa, diri, pekerjaan, kehidupan berbangsa dan tanah air akan menjadikannya sebagai manusia bersih serta bertakwa pada Allah Swt. ${ }^{18}$

2) Makna Istilah Paias Rohamu

Berdasarkan hasil wawancara dengan Armyn Hasibuan, bahwa dalam tubuh manusia terdapat hati yang melahirkan cipta, rasa, dan karsa. Supaya tubuh bisa sempurna ketiga elemen ini harus seimbang, selaras, dan

${ }^{17}$ Hamlan, Dosen Filsafat Dakwah, Fakultas Dakwah dan Ilmu Komunikasi, Wawancara, 12 April 2018.

18 Fauziah Nasution, Dosen Sejarah Dakwah, Fakultas Dakwah dan Ilmu Komunikasi, Wawancara, 20 Agustus 2018. 
serasi. Untuk memperoleh kewajaran itu perlu ada suasana hati yang bersih. Bersih atau kotornya hati dapat diketahui dari tingkah laku. Istilah kotor dan bersih dalam hal ini bersifat abstrak. Jadi mengetahui bersih dan kotornya hati ini manusia dapat menilainya dri pengkajian diri sendiri. ${ }^{19}$ Pemaknaan tentang poin paias rohamu dari konsep poda na lima, dari berbagai narasi dari informan penelitian kepada dosen-dosen yang berkompeten sebagai informan peneliti melihat adanya kesamaan pemahaman dan saling mengisi kekurangan dari pemaknaannya.

3) Kandungan Filosofis Istilah Paias Rohamu

Filosifis dari poin pertama dari poda na lima ini menurut Ali Anas Nasution bahwa hati merupakan pusat pemerintahan diri seseorang, hati memiliki kendali yang sangat signifikan yang dapat menentukan seseorang dalam berbuat benar dan salah. bahkan Nabi Muhammad Saw menyebut bila mana hati seseorang itu baik maka baiklah seluruh tubuhnya, begitu juga bila mana hatinya buruk maka buruklah semua anggota badannya. Maka petuah atau pendidikan yang pertama adalah memperbaiki atau membersihkan hati, yaitu menghilangkan semua penyakit hati seperti dengki, cemburu, syirik dan sebagainya. Peneliti melihat bahwa yang dimaksud "Paias Rohamu" dalam poda na lima adalah padao gut-gut (artinya jauhkan diri dari iri hati kepada orang lain), padao dokki yaitu menjauhkan diri dari sifat dengki kepada orang lain, padao gabus artinya menjauhkan diri dari berbohong, padao paoto-otohon yaitu menjauhkan diri dari membodohi orang lain dan ingot hamatean yakni ingat bahwa manusia semuanya akan mati dohot jangan lupa zikir. Inilah yang menjadi nilai-nilai filosofis yang ditemukan oleh peneliti dari beberapa informan yang sesuai dan mampu menjawab makna filosofis dari konsep poda na lima poin pertama paias rohamu (bersihkan hatimu).

b. Pemahaman Mahasiswa Fakultas Dakwah dan Ilmu Komunikasi tentang Konsep Poda Na Lima Paias Rohamu

Pemahaman poda na lima dikhususkan pada poin paias rohamu di kalangan mahasiswa Fakultas dakwah dan ilmu komunikasi dirangkum pada tiga poin penting yaitu pemaknaan mahasiswa dan urgensinya.

1) Istilah Poda Nalima Paias Rohamu di Kalangan Mahasiswa

19 Armyn Hasibuan, Dosen Akhlak Tasawuf, Fakultas Dakwah dan Ilmu Komunikasi, Wawancara, 2 Agustus 2018. 
Berdasarkan hasil wawancara pada mahasiswa Fakultas Dakwah dan Ilmu Komunikasi IAIN Padangsidimpuan bahwa istilah poda na lima masih terasa asing bagi kebanyakan mahasiswa yang tidak bersuku batak Angkola Mandailing. Peneliti kemudian menelusuri istilah tersebut pada mahasiswa yang layak dan bermarga dari Angkola Mandailing. Berbagai pemahaman mereka dalam memahami istilah poda nalima ini terutama pada poin pertama paias rohamu hampir sama secara konteks, tetapi dalam penerapan berbeda.

Berbagai tanggapan terkait dengan istilah poda na lima pada poin paias rohamu telah mengarahkan bahwa pemahaman mahasiswa Fakultas Dakwah dan Ilmu Komunikasi memahami bahwa paias rohamu merupakan landasan filosofis kearifan lokal dari hasil budaya Angkola Mandailing. Mahasiswa yang memiliki pemahaman terhadap nilai dalam paias rohamu tersebut memiliki konsep diri yang terjaga dan karakter yang dekat dengan kearifan lokal Angkola Mandailing.

2) Urgensi Poda Na Lima Paias Rohamu

Paias atau bersihkan sesuatu yang sangat disukai atau dicintai oleh manusia. Nenek moyang terdahulu sudah mengetahui, memikirkan makna yang hakiki dari bersih, dia telah menilai dan menjabarkan hakikat bersih, pada masa itu belum ada agama. Adapun agama pada masa neneng moyang ini, masalah bersih, sudah disukai dan dicintai. Begitu penting dan dan mendalamnya hakikat dari bersih terhadap diri manusia. Dengan demikian dari rohalah atau hati nuranilah mengorbit, mendesak otak berpikir dan merencanakan sesuatu yang baik dan atau yang buruk, dan dari otaklah memerintahkan panca indra, untuk berbuat sesuatu sesuai dengan desakan hati nuraninya. Bila hati buruk atau jahat, maka buruk pula perilaku manusia itu begitu juga dengan sebliknya.

c. Literasi Media dalam Konsep Paias Rohamu pada Dosen dan Mahasiswa Fakultas Dakwah dan Ilmu Komunikasi

Berdasarkan hasil analisis data riset melalui metode wawancara bahwa adanya literasi media dapat diterapkan melalui nilai sosial budaya yakni tergantung pada cara integrasi pemahaman akan konsep dasar filosofis poda na lima. Seperti halnya dalam mata kuliah akhlak tasawuf, hadist, tafsir, dan berbagai mata kuliah berbasis agama Islam, layaknya nilai konsep budaya poda na lima paias rohamu dapat diterapkan dengan menggaungkan 
istilah tersebut sebagai cara membersihkan diri sebagai dasar dari pembelajaran.

1) Literasi Media pada Berita Hoax pada Dosen Fakultas Dakwah dan Ilmu Komunikasi

Mendefinisikan literasi media tidak hanya dari aspek teknologinya tetapi juga harus menyentuh aspek budayanya yang menjadi konteks dimana literasi media tersebut diciptakan dan diwujudkan guna mencegah serta menanggulangi dampaknya dimana keraifan lokal (local wisdom) merupakan gagasan masyarakat setempat yang bersifat bijaksana, penuh dengan kearifan, bernilai baik yang tertanam nilai-nilai dan diikuti masyarakatnya

Mahasiswa dan dosen kini di Fakultas Dakwah dan Ilmu Komunikasi memang berada pada tahap peralihan/transisi, dari tradisional menuju modern dan teknologi. Hal tersebut merupakan akibat dari peralihan status dari STAIN menjadi IAIN pada 2014 yang lalu selain itu adanya perkembangan teknologi yang semakin mutahir. Perkembangan ini menjadikan mahasiswa dan dosen secara pelahan menuju pada literasi media berita hoax yang muncul dan viral akibat dari perkembangan teknologi media internet tersebut. ${ }^{20}$

2) Literasi Media melalui Sosmed di Kalangan Dosen

Banyak orang memanfaatkan media sosial untuk berinovasi dan berkreasi. Tidak sedikit pula yang menggunakan media sosial entah untuk sekedar iseng mengaktualisasikan diri, mendekatkan diri dengan keluarga di luar daerah, maupun untuk mencari penghasilan. Ironisnya, media online ini dimanfaatkan pula oleh sekelompok orang untuk kejahatan dan hal-hal merugikan lainnya. Penyebaran berita hoax itu terjadi karena adanya dendam, dengki atau merasa tidak suka dengan oknum atau orang tertentu. Akan tetapi hal ini tidak akan terjadi bilamana kebersihan hati seseorang tersebut ada konsep paias rohamu. Jika ia membaca informasi di sosmed ia akan berpikir bahwa apakah ini layak saya bagikan? Itulah mengapa perlu adanya konsep paias rohamu dalam poda na lima. ${ }^{21}$

\footnotetext{
${ }^{20}$ Agus Salim Lubis, Dosen Filsafat Ilmu, Wakil Dekan Bidang Adm Umum dan Keuangan, Fakultas Dakwah dan Ilmu Komunikasi, Wawancara, 22 Agustus 2018

21 Wahyuni Siregar, Dosen Bimbingan Konseling Islam, FDIK IAIN Padangsidimpuan, Wawancara 3 Agustus 2018.
} 
d. Pemahaman Mahasiswa tentang Konsep Poda Na Lima Paias Rohamu dalam Bentuk Literasi Media Memfilte Berita Hoax

Pemahaman mahasiswa tentang poda na lima paias rohamu menjadi sesuatu yang cukup asing bagi mahasiswa yang bersuku selain batak. Hal ini peneliti temukan sebagai sebuah realitas yang wajar. Namun ada juga mahasiswa yang bersuku batak tetapi pemahaman istilah poda na lima paias rohamu kurang mengetahui. Banyak hal yang menjadi kendala awal dalam fokus group diskusi bersama dengan mahasiswa non batak dan yang jauh dari pendidikan budaya batak Angkola Mandailing di dalam keluarganya.

Mahasiswa dalam menerapkan filterisasi berita hoax di fakultas Dakwah dan Ilmu Komunikasi masih minim dengan filterisasi berita hoax secara keseluruhan. Meskipun Fakultas Dakwah dan Ilmu Komunikasi dikenal sebagai mahasiswa yang mumpuni dalam bermedia karena mempelajari ilmu komunikasi. Kenyataan yang peneliti lihat di lapangan bahwa mahasiswa dalam pemahaman literasi media masih minim secara umum.

Peneliti menemukan bahwa sebagian kecil mahasiswa memiliki jiwa bermedia yang aktif dalam memfilterisasi berita-berita hoax dan menyebarkannya kepada rekan sejawatnya bahwa berita tersebut adalah hoax. Proses filterisasi berita hoax yang dilakukan oleh sebagian kecil mahasiswa adalah didasarkan pada pemahaman dan kegemaran berselancar di internet. Selain itu, peneliti juga melihat adanya kemampuan dalam literasi media pada sebagian kecil mahasiswa Fakultas Dakwah dan Ilmu Komunikasi karena faktor didikan keluarga tentang budaya poda na lima dan transfer knowledge dari pola pikir dari para dosen yang paham tentang literasi media.

\section{Upaya Dosen dan Mahasiswa dalam Menanamkan Poda na Lima Paias Rohamu sebagai Bentuk Literasi Media Memfilter Berita Hoax}

Peneliti melihat bahwa upaya para dosen dan mahasiswa sudah ada, hanya saja cara dan pelaksanaan yang berbeda-beda. Upaya yang dilaksanakan dosen dalam menanamkan nilai poda na lima paias rohamu dengan dua cara:

a. Dosen lebih berupaya memberikan pemahaman tentang konsep diri sesuai bidang mata kuliahnya pada mahasiswa melalui pembelajaran di dalam kelas. 
b. Memproduksi pesan sebagai bagian dari kreativitas pesan adalah kemampuan seseorang menyusun pesan atau ide dengan kata-kata, suara, atau imej secara efektif sesuai dengan kaidah-kaidah ilmu komunikasi.

c. Menciptakan media berkaitan dengan produksi dan distribusi isi media, juga berkaitan dengan kompetensi komunikatif.

a. Penanaman nilai kearifan lokal poda na lima dalam memfilterisasi berita hoax dalam bentuk arahan, bimbingan, dan pengkajian secara akdemik dan keilmuan kepada mahasiswa.

Beberapa upaya mahasiswa dalam menamankan poda na lima paias rohamu sebagai dasar literasi media berdasarkan hasil riset peneliti adalah

a. Mahasiswa membaca dan menelaah dengan teliti berita yang tersebar terutama pada akun sosial medianya.

b. Mahasiswa tidak secara langsung membagikan berita yang meskipun menarik tetapi dilakukan pengecekan pada search engine seperti google, bing, maupun yahoo search.

c. Mahasiswa tidak langsung memberikan statement dan komentar miring apabila berita tesebut berbau sara yang tidak sesuai dengan konsepnya.

Meskipun berita tersebut setelah melakukan penelurusan lebih lanjut ternyata buka berita hoax, beberapa mahasiswa sepakat untuk tidak selalu menggunakan share di sosial media. Upaya mahasiswa ini memang masih sedikit namun hal ini adalah perilaku yang pasti dan real.

\section{PENUTUP}

Pemahaman dosen dan mahasiswa di Fakultas Dakwah dan Ilmu Komunikasi IAIN Padangsidimpuan tentang poda na lima paias rohamu (bersihkan jiwamu) tidak semua dosen dan mahasiswa memahaminya dengan baik. Hal ini karena adanya perbedaan budaya sebagai identitas pribadi setiap dosen. Hal inilah yang menjadi kedala dalam membentuk konsep literasi media dalam memfilter berita hoax.

Mahasiwa di Fakultas Dakwah dan Ilmu Komunikasi memanfaatkan media sosial untuk berinovasi dan berkreasi buka pada tatanan bentuk literasi untuk memfilter berita. Konsep tersebut tidak diangkat secara material tetapi lebih pada nilai kandungan dari poda na lima paias rohamu. Mahasiswa Fakultas Dakwah dan Ilmu Komunikasi, untuk bersih dalam buadaya Angkola Mandailing yang telah menjadi warisan filosofis kehidupan bahwa urgensi 
secara umum dari penerapan paias rohamu. Manfaat dari poda na lima sering digunakan pada saat peresmian perkawinan, dimana para hatobangon, ulama cerdik pandai, harajaon, mora, kahanggi banyak memberikan nasehat tentang poda na lima terutama paias rohamu.

Memproduksi pesan sebagai bagian dari kreativitas pesan adalah kemampuan seseorang menyusun pesan atau ide dengan kata-kata, suara, atau imej secara efektif sesuai dengan kaidah-kaidah ilmu komunikasi. Menciptakan media berkaitan dengan produksi dan distribusi isi media, juga berkaitan dengan kompetensi komunikatif. Penanaman nilai kearifan lokal poda na lima dalam memfilterisasi berita hoax dalam bentuk arahan, bimbingan, dan pengkajian secara akdemik dan keilmuan kepada mahasiswa. Mahasiswa membaca dan menelaah dengan teliti berita yang tersebar terutama pada akun sosial medianya. 
380 | TAZKIR: Jurnal Penelitian Ilmu-ilmu Sosial dan Keislaman

Vol. 04 No. 2 Desember 2018

\section{DAFTAR PUSTAKA}

Apriadi Tamburaka, Literasi Media, Jakarta: Rajawali Pers, 1995.

Imam An-Nawawi. Matan Hadits Arba'in An-Nawawi. Solo: Insan Kamil, 2013.

Jan H. Brunvand, Encyclopedia of Urban Legends. W. W. Norton \& Company, 2001.

Rahmi. Pengenalan Literasi Media Pada Anak Usia Sekolah Dasar. Jurnal SAWWA, 2013. No. 8 Vol 2, hlm. 261-275. Diakses dari http://journal. walisongo.ac. id/index.php/sww/article/view/116

Silverblatt Art. Media Literacy: Key To Interprenting Media Massages. USA: Publisher Preager, 1995.

Stanley J. Baran, Pengantar Komunikasi Massa: Literasi Media dan Budaya, Edisi Kelima Buku Satu, Jakarta: Salemba Humanika, 2011.

Sugiyono, Memahamai Penelitian Kualitatif, Bandung: Penerbit Alfabeta, 2005.

Suharsimi Arikunto, Metode Penelitian Teori dan Praktek, Jakarta: Rajawali, 2010.

Sutan Tinggi Barani Perkasa Alam dan Zainal Efendi Hasibuan, Adat Budaya Batak Angkola Menelusuri Perjalanan Masa, Medan: Parmata Mitra Sari, 2015.

Sutan Tinggi Barani Perkasa Alam, Pembaharuan dan Modernisasi Adat Budaya Tapanuli Selatan Adat Hombar Dohot Ibadat dalam Pelaksanaan, Padangsidimpuan, TP, 2005.

Tim Penyusun, Kamus Bahasa Indonesia, Jakarta: Departemen Pendidikan dan Kebudayaan, 2008.

W. James Potter, Theory of Media Literacy: A Cognitive ApproachLondon:Sage, 2004.

Wikipedia, Pemberitaan Palsu, Diakses pada laman: https://id.wikipedia.org/wiki/ Pemberitaan_palsu, Diakses 21 Juni 2017.

Yosep Adi Prasetyo Ketua Dewan Pers Indonesia, Ini Ciri-ciri Hoax Menurut Ketua Dewan Pers, Diakses dan dimuat pada Laman: https://www.bnpt.go.id/ini-ciri-ciri-hoax-menurut-ketua-dewanpers.html

Zainal Efendi Hasibuan dan Sutan Tinggi Barani Perkasa Alam, Studi Komprehensif Adat Budaya Batak Angkola Menelusuri Jejak Nilai- Nilai Luhur Adat Budaya dan Agama Ditanah Batak Angkola dalam Membentuk Generasi Muda yang Berkarakter dan Beradab, Padangsidimpun, TP, 2013. 